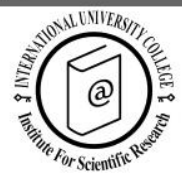

\title{
The satisfaction of wine tourist: causes and effects
}

\author{
Cristina de la Orden Reyes ${ }^{1}$
}

Received: 07/01/2012

\begin{abstract}
${ }^{1}$ University of Huelva (Spain), GEIDETUR, Faculty of Business Studies, Plaza de la Merced, 11. 21002Huelva, Spain, phone: (+34)661816631, e-mail: cristina.delaorden@dem.uhu.es, cdelaorden@hotmail.com
\end{abstract}

Supervisor: Dr. Alfonso Vargas Sánchez

Institution awarding the Ph. D. Degree: University of Huelva, Spain

Date of defence: $22^{\text {th }}$ September 2011

(c) 2012 International University College. All rights reserved

Citation: Reyes, C. (2012), The satisfaction of wine tourist: causes and effects. Doctoral dissertation summary. European Journal of Tourism Research 5(1), pp. 80-83

\section{Goal and objectives of the dissertation} Goal

To analyze oenologist cultural tourist satisfaction, identifying its causes and the effects that can determine the tourist experience.

\section{Objectives}

To develop a model explaining the causes of satisfaction / dissatisfaction of tourists and the effects of it, tested in a given environment, specifically the Huelva County ("Condado de Huelva", in the Spanish region of Andalusia) wineries. This overall objective was broken down in nine more specific objectives, identifying:

Objective 1: The individuals' expectations before the visit to the winery.

Objective 2: The perception of quality of service.

Objective 3: The perception of price-quality relationship (i.e. value).

Objective 4: The perception of overcrowding degree.
Objective 5: The perception of promotioncommunication efforts.

Objective 6: The level of perceived authenticity. Objective 7: The degree of visit satisfaction.

Objective 8: The level of repetition to the destination.

Objective 9: The recommendation to friends and family members.

\section{Methodology}

In the first part of this thesis, the classic methodology of a comprehensive review of the scientific literature was used, based on which the model was created to be tested. The second section is aimed to describe the geographic area where the empirical study was performed (called "Condado de Huelva", an area with a very long tradition of wine production, located in the extreme south-west of Andalusia, Spain). The third part is devoted to the empirical study, in which the technique of Partial Least Squares (PLS) has been used to test the hypotheses of our research model; for this purpose a measurement instrument (questionnaire) was designed and validated. 
Results

\begin{tabular}{|l|l|}
\hline CHARACTERISTICS & SAMPLE \\
\hline Universe & Visitors to the wineries of Huelva County (Andalusia, Spain). \\
\hline Geographical scope & $\begin{array}{l}\text { Two municipalities: La Palma del Condado and Bollullos par del } \\
\text { Condado. }\end{array}$ \\
\hline Sample size & 400 valid data. \\
\hline Sampling error & $4,9 \%$ \\
\hline P value & $95 \% \quad z=1,96 \quad p=q=0,5$ \\
\hline Sample design & $\begin{array}{l}\text { Simple random sampling from a population of infinite size. } \\
\text { Estimation of a mean or proportion, assuming a normal } \\
\text { sampling distribution. }\end{array}$ \\
\hline Data collection method & $\begin{array}{l}\text { Structured questionnaire, with items presented in the form of } \\
\text { five-points Likert scales. }\end{array}$ \\
\hline Date of fieldwork & June-November 2010. \\
\hline
\end{tabular}

Conclusions, limitations and future research lines integrate the last section.

In the subsequent table, the data sheet with the characteristics of the sample is presented.

We have concluded that:

$\checkmark$ Following the values of composite reliability obtained for all the constructs in this study, they have a quite acceptable degree of internal consistency.

$\checkmark$ Similarly, their convergent validity is another feature to underline (at least $50 \%$ of the variance is due to all its indicators).

$\checkmark \quad$ It also notes the existence of discriminant validity in the measures, which has been verified through the AVE (Average Variance Extracted).

Specific results:

$\checkmark \quad$ The set of variables analyzed in our study predicts $56.68 \%$ of the oenologist cultural tourist satisfaction.

$\checkmark \quad$ The impact of authenticity on the visitor's satisfaction is the highest, coming to explain $33.699 \%$ of its variance.

$\checkmark$ Another variable that impacts the most over tourist satisfaction is the perceived value for money, with $13.70 \%$. $\checkmark$ Overcrowding has virtually no effect on tourist satisfaction: it only reaches a value of $0.5 \%$ of the total variance of satisfaction.

$\checkmark$ Satisfaction is able to explain $43.42 \%$ of the loyalty's variance.

\section{Theoretical Conclusions}

After reviewing the literature on cultural tourist satisfaction, we have noted that there are some variables that act as predictors of satisfaction, which have been taken into account in our research model. These include the variable authenticity, which is understood from three perspectives or dimensions: human, physical and contextual. Apparently, tourists look for places that maintain a balance between the original and the modern, but without falling into the commodification of local traditions, that goes on to become a mere object of consumption.

Another variable that most influences the satisfaction is the price-quality variable, so we can therefore say, consistently with the literature findings, that tourists are not out to the influence of the price paid when visiting a winery. 
Regarding the variable overcrowding, we must consider that in our study did not influence tourist satisfaction because of the study was carried out in an oenologist cultural tourism emerging destination, so it is not yet visible a clear decrease in the level of satisfaction with the experience because of the overload of people visiting the place. As a consequence, the stage of the life cycle of the destination under study should be considered as a contingent variable when researching this phenomenon.

Finally, with respect to the variable fidelity, it indicates that the satisfied customer is usually faithful to the destination and this entails the recommendation to the family members and friends, and even repeating (or willingness to repeat) the visit to the destination in the future. This is also consistent with the literature review.

In summary, we can say that the oenologist cultural tourist gives the most importance to variables such as authenticity and value for money, and that, in addition, there is a high probability of becoming a prescriber of the destination and selflessly make a good promotional campaign / communication.

\section{Practical application of the dissertation}

The study provides knowledge of the cultural profile of tourists visiting the wine region of "Huelva County", an area that is located in the province of Huelva, in the South-West of Spain. This is an emerging oenologist tourism destination where winemakers, motivated by their own supply and demand, are being forced to adapt to the new tourist idiosyncrasies.

Therefore, we can affirm that, in this particular context, winery owners should be aware that tourist satisfaction of visitors to their wineries are mainly based on variables such as authenticity (studied from three dimensions: human, physical and contextual) and pricequality relationship.

In those circumstances we face a tourist with a good level of overall satisfaction with the visit to those wineries, which drives into a more loyal customer to that destination, willing to recommend it to family and friends through the mouth-ear and with the intention of visiting the destination back in the future.

Therefore, the winemaking families should be aware of (and be able to maintain) the main influencing variables (mentioned above) for tourism development, as currently, Condado de Huelva wineries have ceased to be mere centres of production and shipments of wine to become places with a kind of tourist attraction.

In a nutshell, we believe that with this study we were able to make public and private managers see the potential for economic and social development offered by wine tourism for them, taking into account a number of strategic variables.

\section{Content of the dissertation}

\section{Abstract of chapter one}

This chapter starts with an overview of the evolution of tourism. It offers different definitions of the term, analyzing different impacts, both positive and negative, that such activity may develop in a certain place. Afterwards, it focuses on the study of cultural tourism types, definitions, general considerations and a SWOT analysis of the situation in Spain.

\section{Abstract of chapter two}

Here we have shown different definitions of cultural tourist, the motivations that lead it to make a tour and the types of cultural tourists according to different criteria, ending with a section on cultural tourism demand in the province of Huelva.

\section{Abstract of chapter three}

In this chapter we have set all the variables that influence the tourist's satisfaction, taking into account the different contexts, and the consequences it should generates in terms of loyalty.

\section{Abstract of chapter four \\ In this chapter we have focused on the development of wine tourism and the definition of oenologist tourist as well as the different types that are present on it.}




\section{Abstract of chapter five}

This chapter is dedicated to the study of the area where the field work is carried out, the "Condado de Huelva" (as a designation of origin and guarantee of quality) and its wines, focusing in the two main wine producers municipalities: La Palma del Condado and Bollullos Par del Condado.

\section{Abstract of chapter six}

We present the model that represents the process of satisfaction of visitors to the wineries, where the variables are divided into three groups: the perception variables influencing tourist satisfaction, the variables related to the destination, and the effects caused by tourist satisfaction. All of them are connected in a number of hypotheses shown in the research model. The methodology undertaken to test these hypotheses is also explained in this chapter.

\section{Abstract of chapter seven}

In this chapter we present the results obtained from the data collected through the questionnaire, which has been treated with the SPSS 18.0 and PLSGRAPH. We proceeded to study the reliability and validity of each of the multi-item scales and, finally, to contrast the proposed model through a structural equation analysis.

\section{Abstract of chapter eight}

It outlines the main conclusions provided by the study, both theoretical and practical ones.

\section{Abstract of chapter nine}

Finally, this chapter details the references used for conducting that research. 